\title{
Temporal edge effects structure the assemblages of Drosophilidae (Diptera) in a Restinga forest fragment in Southern Brazil
}

\author{
Mayara Ferreira Mendes ${ }^{1}$, Monica Laner Blauth², Luana Amaral Dos Santos ${ }^{3}$, \\ Vera Lúcia da Silva Valente Gaiesky ${ }^{1}$, Marco Silva Gottschalk ${ }^{2}$
}

1 Programa de Pós-Graduação em Biologia Animal, Universidade Federal do Rio Grande do Sul, Porto Alegre, Rio Grande do Sul CEP 91509-900, Brazil

2 Departamento de Ecologia, Zoologia e Genética, Instituto de Biologia, Universidade Federal de Pelotas, Pelotas, Rio Grande do Sul CEP 96010-900, Brazil

3 Programa de Pós-Graduação em Entomologia, Universidade Federal do Paraná, Curitiba, Paraná CEP 81.531-980, Brazil

Corresponding author: Mayara Ferreira Mendes (ferreiramendesmayara@gmail.com)

Academic editor: P. Nunes-Silva | Received 30 November 2020 | Accepted 15 March 2021 | Published 12 May 2021

Citation: Mendes MF, Blauth ML, Dos Santos LA, Gaiesky VLSV, Gottschalk MS (2021) Temporal edge effects structure the assemblages of Drosophilidae (Diptera) in a Restinga forest fragment in Southern Brazil. Neotropical Biology and Conservation 16(2): 299-315. https://doi.org/10.3897/neotropical.16.e61481

\begin{abstract}
Anthropogenic habitat fragmentation directly affects ecological processes, leading to negative biodiversity impacts for insects and other biota. Increased edge effects are one consequence of fragmentation, and may alter the composition or abundance of species in the remaining habitat fragments. Understanding the ways in which edge effects impact upon the biota is essential for conservation decision-making in fragmented landscapes. Therefore, the aim of this study was to analyze the seasonal patterns of abundance, richness, and composition of Drosophilidae in a Restinga forest fragment in the extreme south of Brazil, as a function of the distance from the edge to the interior of the fragment. The data were analyzed using SIMPER analyses, which showed that the edge and the forest interior were most dissimilar during winter, followed by spring, autumn and summer. An NMDS and the SIMPER analyses showed that the lower dissimilarity between the edge and interior in spring, autumn and summer, compared to winter, is driven by immigration of individuals from outside of the forest fragment. Furthermore, some species were asymmetrically distributed in the fragment, with some species restricted to the edge of the fragment and others to the interior. This information aids in the understanding of the functioning and dynamics of fragmentation, which is fundamental for the maintenance and integrity of environments and their fauna.
\end{abstract}




\section{Keywords}

Drosophilinae, environmental detectors, exotic species, habitat fragmentation, Neotropical forest, species composition

\section{Introduction}

Habitat fragmentation, loss, and degradation are the most important causes of declining insect assemblages, as a result of impacts on both ecological patterns, such as species diversity, and ecological processes, such as dispersal (Murcia 1995; New et al. 1995; New 1997). The impacts of habitat fragmentation on biodiversity include reduced dispersal rates, decreased effective population size, loss of genetic variability, invasion of exotic species and increases in the total area subject to edge effects (Fahring 2003; Ewers and Didham 2007; Laurance et al. 2007). Edge effects are characterized by an increase in the proportion of forest edge relative to the proportion of forest interior, which causes structural changes and increases the exposure of organisms that are inside the fragment to the conditions of a different ecosystem (Murcia 1995). Which means that we can define edge as the line used to demarcate two adjacent ecosystems where both are separated by an abrupt transition also referred to as ecotone (Murcia 1995; Lennon et al. 1997).

The strength of edge effects is related to the distance to the edge of the fragment, and can differ between environmental variables. For example, the increases in solar radiation levels, temperature variations, relative humidity and wind, are variables that have a stronger influence on the microenvironment (Kapos 1989; Bierregaard et al. 1992). These changes modify the composition of biotic communities and affect biological processes, including interactions between species (Laurence 2000).

Many insect species are used as ecological indicators, such that changes in their abundance are considered indicative of degradation in different habitats (Neto et al. 1995; Ries and Debinski 2001; Wink et al. 2005, Gadelha et al. 2009; Oliveira et al. 2014). Drosophilidae flies are especially sensitive to anthropogenic actions and as such are frequently used to monitor habitat degradation (Martins 1989; Ferreira and Tidon 2005; Gottschalk et al. 2007; Mata et al. 2008; Mata et al. 2010; Penariol and Madi-Ravazzi 2013; Cavasini et al. 2014). There are currently 76 described Drosophilidae genera, with more than 4200 described species (Bächli 2021). In the Neotropical region, Sturtevant (1921) studied the distribution of Drosophilidae species and found 82 species distributed across 13 genera. The family is morphologically diverse, and has diversified its use of trophic resources (mainly fruits, flowers and macroscopic fungi) (Powell 1997; Schmitz and Valente 2019), such that species of varying sizes and dispersal abilities are found within each biogeographical region.

The present study aims to examine how Drosophilidae assemblages are impacted by edge effects in a Restinga forest fragment, and how these impacts vary seasonally. To the best of our knowledge, this is the first study to examine these dynamics. Specifically, we seek to understand: (i) the impact of edge effects on the composition, abundance and species richness of Drosophilidae in a forest fragment, and (ii) whether the sensitivity of Drosophilidae to edge effects differs between seasons. 


\section{Materials and methods}

\section{Study area}

The study was conducted in the Horto Botânico Irmão Teodoro Luís (HBITL), a Restinga forest fragment located in the municipality of Capão do Leão (-31.815124S, -52.432228 W, elevation about $16 \mathrm{~m}$ ) in the state of Rio Grande do Sul, Brazil (Fig. 1, according to Google Earth and Geographic Information Science 2001). The HBITL has a total area of approximately 25 hectares (Guerra et al. 2015), lies approximately $50 \mathrm{~km}$ inland from the coast, and is a permanent preservation area. In the study region, the predominant climate is humid subtropical "Cfa", according to the Köppen classification (Alvares et al. 2013), and is made up of four distinct seasons (Spring: October to December, Summer: January to March, Autumn: April to June, and Winter: July to September). Seasonal variation is marked by a reduction in temperatures in winter, while rainfall and relative humidity remain almost constant throughout the year (IBGE 1997). The environmental data used in this study (daily average temperature, cumulative precipitation and relative humidity in each season) were collected at the Estação Agroclimatológica de Pelotas (1988) between February/2013 and January/2014 (see Figure 2).

The study area is composed of a mosaic of Restinga forest surrounded by wetlands and anthropogenic habitats, including pastures and a few low buildings. The forest consists of different strata: trees, shrubs, and herbaceous plants, with xeromorphic, succulent and thorny vegetation (Rodrigues 2005). Large fig trees are common at the canopy level, which has a height of approximately eight meters.

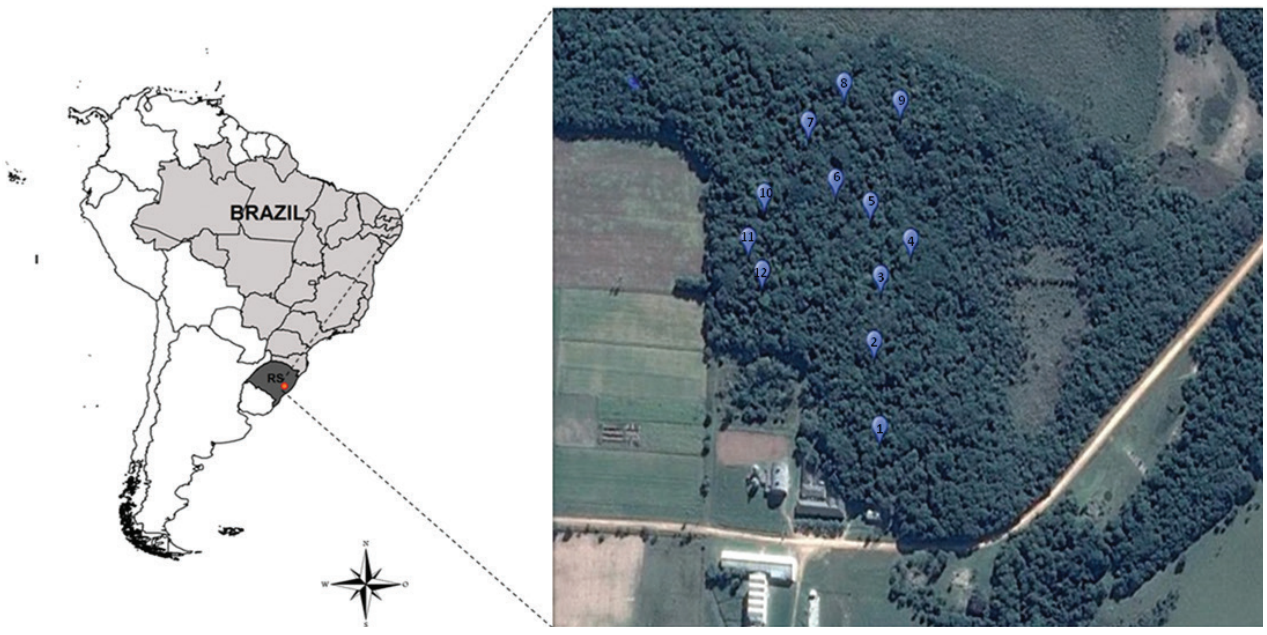

Figure 1. Map data 2013 of South America highlighting Brazil (in gray) and the location of the Horto Botânico Irmão Teodoro Luís in Restinga Forest (HBITL - red dot) in the state of Rio Grande do Sul (in dark gray). Blue dots - indicate the location of each trap in the HBITL. According Google Earth, accessed in http://www.google.com.br/earth/ 

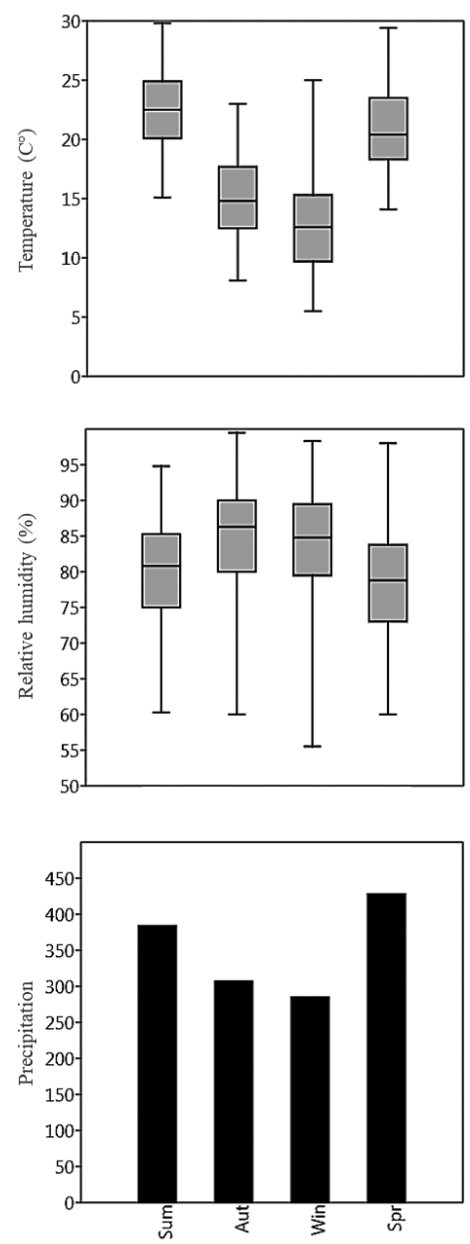

Figure 2. Average A: mean daily temperature $\left({ }^{\circ} \mathrm{C}\right)$, B: cumulative precipitation $(\mathrm{mm})$ and $\mathbf{C}$ : relative humidity (\%) of the seasons during the study (spring (Spr): October to December, summer (Sum): January to March, autumn (Aut): April to June, and winter (Win): July to September). In the box plots, the boundary of the gray box indicates the $50 \%$ central percentile, the black line within the box marks the median, and the whiskers above and below the box indicate the lower and higher $25 \%$ percentiles.

\section{Restinga features and landscape data}

Geologically, the most accepted definition for Restinga refers strictly to recent and unstable sandy strips in the coastal region, with practically no vegetation covering the sand, or with only undergrowth (Souza et al. 2005). However, in plant ecology, the coastal vegetation of Restinga is defined by different forms of vegetation established on sandy soils that occur in the region of the coastal plain (Azevedo et al. 2014). These soils originate predominantly through marine deposition during the sea-level retreat phases in different geological periods, not only recent depositions (Souza et al. 2005). 
The established vegetation is not homogeneous in the coastal plain since there are different factors defining the environmental conditions and, consequently, the type of vegetation that is established. Among these factors is the distance from the sea, as salinity, wind strength, and temperature varies along this gradient. Another factor is the topography of the terrain, which is associated with the processes of deposition and removal of soil in these regions (Araújo 1984; Souza et al. 2005; Scarano 2009; Azevedo et al. 2014). In addition, the vegetation itself, when established, changes the environmental conditions and allows for the occurrence of vegetative succession, such that organisms can select microhabitats in which to live (Araújo 1984; Ricklefs 2003; Scarano 2009).

In this study, we described the vegetation structure at each compass point at a distance of $30 \mathrm{~m}$ from each trap (composition and landscape configuration) recorded for February 2013 to January 2014, which were defined according to Restinga ecology established in resolutions 07/1996 and 417/2009 of the National Environmental Council (CONAMA) (Table 1).

\section{Sampling and statistical analysis}

Data were collected monthly between February 2013 and January 2014, inside the forest fragment. Adult Drosophilidae were sampled using 12 retention traps, according to Tidon and Sene (1988), hung $1.5 \mathrm{~m}$ high, and spaced $60 \mathrm{~m}$ apart, over three days each month (Mendes et al. 2017). Each trap contained 150 grams of smashed banana mixed with 25 grams of fresh baker's yeast (Saccharomyces cerevisiae). The shortest distance between each trap and the edge of the fragment was measured in the field using a measuring tape, and was later verified from satellite images captured in February 2013 (using Google Earth and Geographic Information System software). Unfortunately, we were not able to consider $0 \mathrm{~m}$ from the edge of the fragment in this study, due to anthropogenic activities around the fragment.

Table 1. Characterization of the vegetation around the twelve sampled points from the interior to the edge of a Restinga fragment in Southern Brazil, from February 2013 to January 2014, following Azevedo et al. 2014.

\begin{tabular}{lcccc}
\hline Trap & Sites & Latitude / Longitude & Distance & Phytophysiognomy \\
\hline Point 1 & edge & $-31.815987 \mathrm{~S},-52.432165 \mathrm{~W}$ & $68 \mathrm{~m}$ & Arboreal with open canopy, high presence of exotic plant \\
Point 2 & edge & $-31.815124 \mathrm{~S},-52.432228 \mathrm{~W}$ & $75 \mathrm{~m}$ & Arboreal with closed canopy \\
Point 3 & interior & $-31.814578 \mathrm{~S},-52.432152 \mathrm{~W}$ & $114 \mathrm{~m}$ & Dense vegetation with arboreal phytophysiognomy \\
Point 4 & interior & $-31.814299 \mathrm{~S},-52.431723 \mathrm{~W}$ & $101 \mathrm{~m}$ & Dense vegetation with arboreal phytophysiognomy \\
Point 5 & interior & $-31.814106 \mathrm{~S},-52.432241 \mathrm{~W}$ & $168 \mathrm{~m}$ & Dense vegetation with arboreal phytophysiognomy \\
Point 6 & interior & $-31.813892 \mathrm{~S},-52.432732 \mathrm{~W}$ & $153 \mathrm{~m}$ & Dense vegetation with arboreal phytophysiognomy \\
Point 7 & interior & $-31.813410 \mathrm{~S},-52.433035 \mathrm{~W}$ & $107 \mathrm{~m}$ & Arboreal with closed canopy \\
Point 8 & edge & $-31.813077 \mathrm{~S},-52.432518 \mathrm{~W}$ & $80 \mathrm{~m}$ & Arboreal with open canopy, flooded \\
Point 9 & edge & $-31.813302 \mathrm{~S},-52.431736 \mathrm{~W}$ & $78 \mathrm{~m}$ & Arboreal with open canopy, flooded \\
Point 10 & edge & $-31.813860 \mathrm{~S},-52.433489 \mathrm{~W}$ & $63 \mathrm{~m}$ & Arboreal with closed canopy \\
Point 11 & edge & $-31.814267 \mathrm{~S},-52.433704 \mathrm{~W}$ & $46 \mathrm{~m}$ & Arboreal with closed canopy, high presence of exotic plant \\
Point 12 & edge & $-31.814588 \mathrm{~S},-52.433527 \mathrm{~W}$ & $66 \mathrm{~m}$ & Arboreal with closed canopy, high presence of exotic plant \\
\hline
\end{tabular}


The sampled individuals were fixed in $70 \%$ ethanol and prepared according to Wheeler and Kambysellis (1966) and Kaneshiro (1969). The individuals were identified to species level based on external morphology and male genitalia, using an Olympus CL 6000 stereomicroscope, and following identification keys (Freire-Maia and Pavan 1949; Wheeler and Kambysellis 1966; Grimaldi 1987). Females of sibling species were identified by external morphology and, when possible, the species level was determined according to the quantities of males in each trap for analysis purposes. Voucher specimens of all recorded species were deposited in the Drosophilidae Collection of the Museum of Natural Sciences Carlos Ritter (MCNCR) of the Universidade Federal de Pelotas, in the state of Rio Grande do Sul, in Brazil.

The number of species (S) and total abundance of individuals $(\mathrm{N})$ sampled per month were recorded for each trap. To increase the robustness of the data, the total $\mathrm{S}$ and $\mathrm{N}$ of the traps in the same geographical coordinate of all collection events was added and analyzed by season of the year. Most inventoried insect assemblages show temporal variation in abundance and species richness (Heimonen et al. 2013; Poppe et al. 2013; Haridas et al. 2016; Mateus et al. 2018), including those sampled in this study, thus we sampled three times per season. As such, we had larger sample coverage and, at the same time, did not overestimate the distance relations to the edge, replicating the traps inside the fragment.

When working with gridded biodiversity data there is always the potential for spatial autocorrelation, and as such we used Mantel tests (Mantel 1967) with Jaccard and Morisita indices (Jaccard 1900; Krebs 1999) to check for spatial autocorrelation of the species composition between the traps in each season of the year . In each analysis, the significance level was calculated with 999 permutations. To perform the tests, geographic coordinates in UTM (Universal Transverse Mercator) were determined for the position of each trap. The distances between traps were calculated based on the Euclidean distance (Saito and Toriwaki 1994). We also tested spatial dependence of total N and S with Moran's I tests (Moran 1950) with 999 permutations. These analyses were conducted in program $\mathrm{R}$ version 3.1.2 ( $\mathrm{R}$ Core Team 2013) using the vegan and ade4 packages (Dray and Dufour 2007; Oksanen et al. 2008, from Ecological Data Analysis 2002). As we did not detect differences between our observed data and a random pattern (with one exception in the spring samplings using a Mantel test with the Morisita index), the traps were used as the statistical sample unit for analysis (Suppl. material 1: Table S1).

To compare species composition between sample units as a function of the distance to the edge of the fragment, a non-metric Multidimensional Scaling (NMDS) analysis was performed using the Bray-Curtis similarity index, after a logarithmic transformation of the absolute abundance in each sample unit. Shepard's plots (scatter plots of the distances between data points), with stress values (that reflect how well the ordination summarizes the observed distances among the samples), were plotted. Subsequently, the values of the first two axes resulting from the analysis were compared with the distance between each trap and the edge of the fragment, using a Spearman correlation analysis. 
Finally, a SIMPER test was performed using the Bray-Curtis similarity index with the absolute abundances, where the distances were categorized as interior $(>100 \mathrm{~m})$ and edge $(<100 \mathrm{~m})$, to verify which taxa most contribute to explain the difference in species composition between the traps (Vickery 2002). These statistical analyses were conducted using the software PAST version 2.17c (Hammer et al. 2001).

\section{Results}

Over the study period, a total of 25,081 adult specimens were sampled (Suppl. material 1: Table S2), distributed in 46 species belonging to five genera (Drosophila Fallen 1823, Zygothrica Wiedemann 1830, Hirtodrosophila Duda 1923, Leucophenga Mik 1886 and Zaprionus Coquillett 1901). Eighteen species were restricted to a particular microenvironment (Suppl. material 1: Table S2), with approximately $80 \%$ of the species being found in both the interior and the edge of the fragment (Suppl. material 1: Table S3).

In winter, both species richness and absolute abundance of Drosophilidae were significantly positively correlated with distance to the edge of the fragment (Suppl. material 1: Table S3, Fig. 3, p < 0.05), such that both increase with increasing distance from the edge. The correlation is highest for absolute abundance where the points are closest to the trend line (Figure 3). In all other seasons, species richness and absolute abundance did not fluctuate as a function of the distance from the edge of the fragment. Overall abundance and species composition did not vary between the edge and the interior of the forest fragment, however, this pattern varied between seasons. In winter, both species richness and absolute abundance of Drosophilidae were significantly positively correlated with distance to the edge of the fragment.

The results of the NMDS analysis differed between seasons, with a clear segregation of the interior and edge points only in winter (Fig. 4), when the distance to the edge of the fragment was one of the most important factors for the species composition of the Drosophilidae assemblage. Distance to the edge of the fragment was highly correlated with component 1 in winter (Table 2). The species composition of edge and interior assemblages did not differ significantly in the other seasons, nor was there a relationship between the components obtained in the NMDS analysis and the distance to the edge of the fragment (Table 2).

Table 2. Spearman's correlation index values (Rs) and significance (p) of the correlations between coordinates 1 and 2 obtained in the NMDS analysis and the distance to the edge of a Restinga fragment in the South of Brazil, for the four seasons of the studied year.

\begin{tabular}{lccccccccc}
\hline & \multicolumn{2}{c}{ Winter } & \multicolumn{2}{c}{ Spring } & \multicolumn{2}{c}{ Summer } & Autumn \\
\cline { 2 - 8 } & Rs & p & Rs & p & Rs & p & Rs & p \\
\hline Coordinate 1 & -0.888 & 0.0001 & 0.224 & 0.484 & -0.021 & 0.948 & -0.455 & 0.138 \\
Coordinate 2 & 0.0559 & 0.863 & -0.434 & 0.159 & -0.014 & 0.966 & -0.028 & 0.931 \\
\hline
\end{tabular}




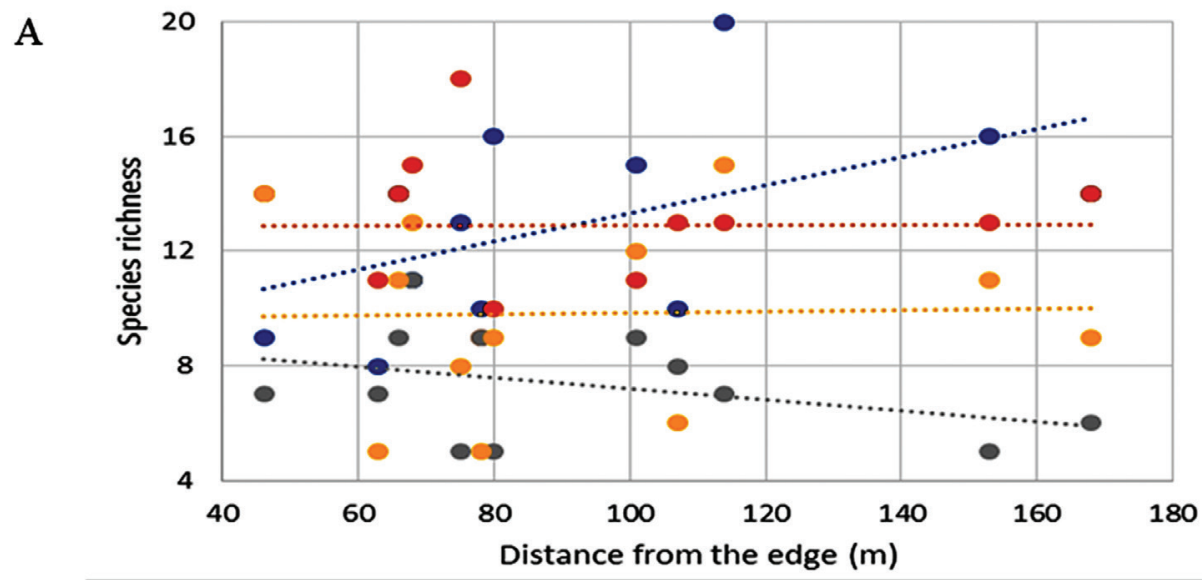

B

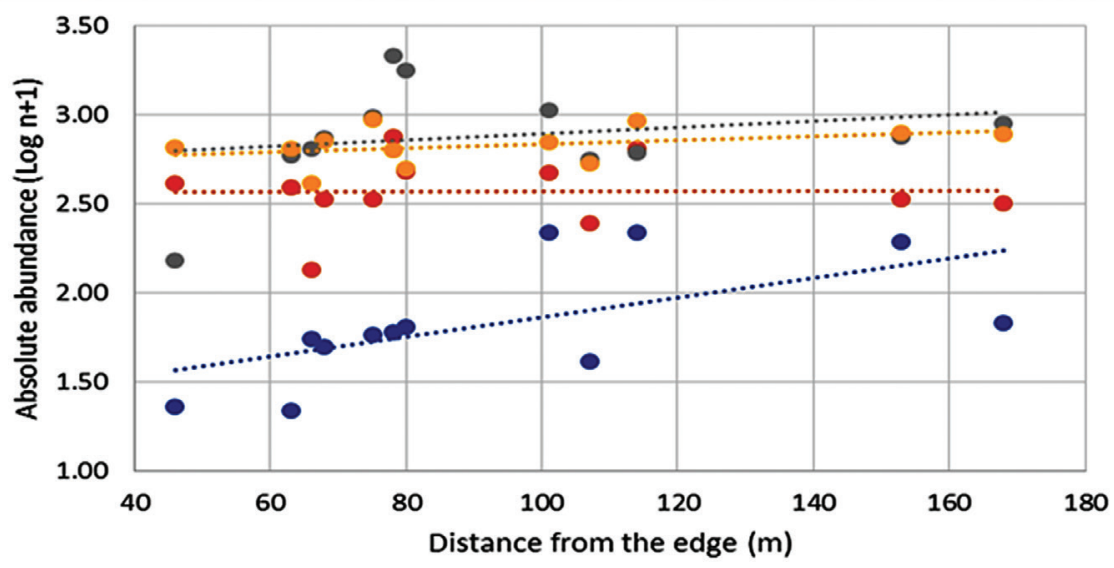

Figure 3. Relationship between species richness (A) and absolute abundance (B) of Drosophilidae and the distance to the edge of a Restinga forest fragment in southern Brazil. Four seasons of the year were sampled and are represented by different colors - Blue line: winter; red line: spring; yellow line: summer; gray line: autumn.

The SIMPER analysis also showed that the dissimilarity between the assemblages at the edge and in the interior of the forest was highest in winter $(71.32 \%)$, followed by Spring (46.73\%), Autumn (33.09\%) and Summer (21.98\%). The two most important species explaining the difference in species composition between the edge and interior assemblages in winter were the native species Zygothrica orbitalis and Drosophila paraguayensis, contributing $33.9 \%$ and $17.9 \%$, respectively, to the dissimilarity between the two environments. These species are followed by three further native species: Drosophila mediopunctata Dobzhansky and Pavan, 1943, Drosophila ornatifrons Duda, 1927 and Drosophila griseolineata Duda, 1927, all of which were more abundant in the interior of the forest, and two exotic species: Drosophila simulans Sturtevant, 1919 and Drosophila immigrans Sturtevant, 1921, which were both more abundant at the edge of the forest fragment (Suppl. material 1: Table S4). 
A

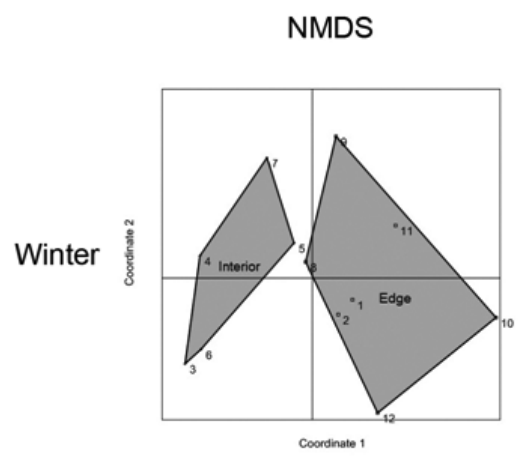

C

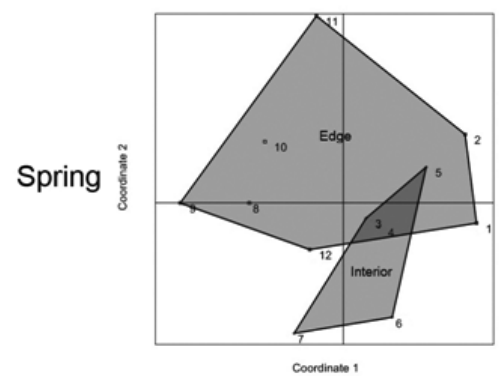

$E$

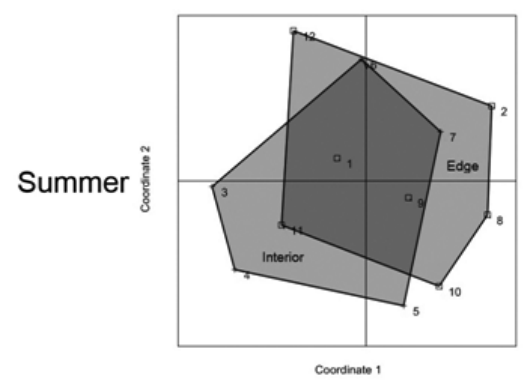

G

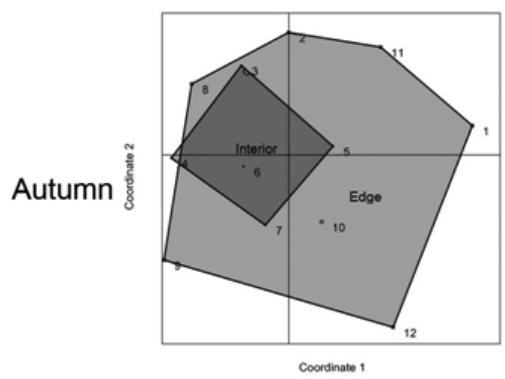

B

\section{Shepard plot}

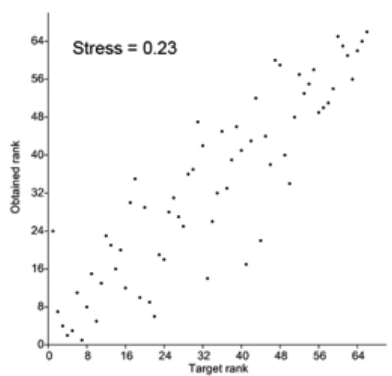

D

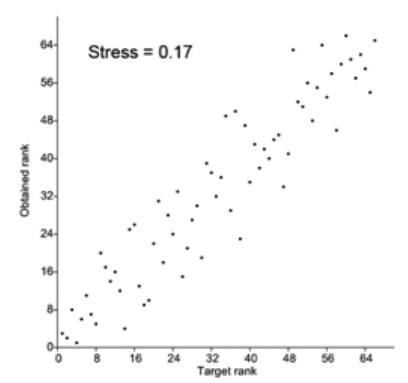

$\mathrm{F}$

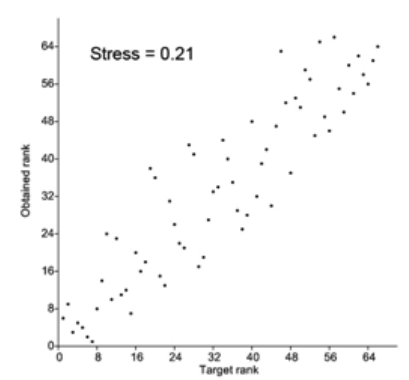

$\mathrm{H}$

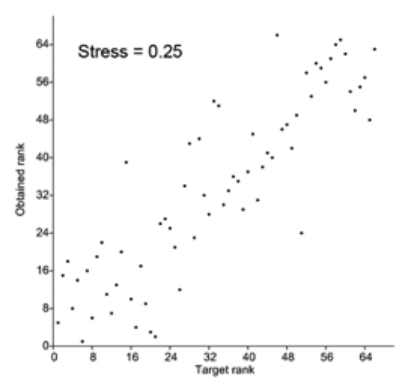

Figure 4. NMDS ordering analysis with the Bray-Curtis similarity index for the Drosophilidae assemblages sampled in a Restinga fragment in southern Brazil for the four seasons of the year. A-B winter; C-D spring; E-F summer; G-H autumn. A, C, E, F Coordinates 1 and 2 generated in the NMDS analysis and plotted. B, D, F, H Shepard's plots with the stress values of each analysis. 
In the other seasons (Suppl. material 1: Tables S5-S7), the assemblage was dominated by D. simulans Sturtevant, 1919 and the Drosophila willistoni subgroup. In spring and autumn, $D$. simulans was the most abundant and contributed the most to the dissimilarity between the edge and the interior of the forest $(55.3 \%$ and $59.1 \%$, respectively), being more abundant at the edge of the forest than in the interior in both seasons (Suppl. material 1: Tables S5, S7). In Summer, the D. willistoni subgroup was the most abundant and contributed the most (71.9\%) to the dissimilarity between the interior and the edge of the forest (Suppl. material 1: Table S6). Drosophila polymorpha Dobzhansky and Pavan, 1943 is the third most abundant species in spring, summer and autumn, however its abundance does not vary with distance from the edge of the fragment. It should also be noted that overall, in Spring, Summer, and Autumn, the differences between the edge and the interior of the forest are small.

\section{Discussion}

Studies have shown that some species of Drosophilidae can be used as indicator species for monitoring environmental degradation (Ferreira and Tidon 2005; Gottschalk et al. 2007; Mata et al. 2008). However, although studies have verified the edge effect in forest areas (Döge, Valente and Hofmann 2008; Furtado and Martins 2018), few have tried to identify which species are associated with edge habitats (Penariol and Madi-Ravazzi 2013). Our results suggest that some species present habitat use strategies, at least in the winter, leading to a significant difference in abundance and species composition between the edge and interior of the fragment. However, this difference did not exist in other seasons, where the fauna in the interior of the forest fragment is similar to that of the edge.

While previous studies have shown an association between dominance and temporal variation in species abundance and different environmental variables in distinct environments (Saavedra et al. 1995; Torres and Madi-Ravazzi 2006; De Toni et al. 2007; Poppe et al. 2013; Mendes et al. 2017; Mateus et al. 2018), here we show that other factors determine the distribution of Drosophilidae species in Restinga fragments, and that the edge effect is seasonal.

As Penariol and Madi-Ravazzi (2013) had previously found, our results show that the abundance of both Drosophila simulans Sturtevant, 1919 and the D. willistoni subgroups are affected by the distance to the edge of the fragment, with the former being more abundant at the fragment edge and the latter in the interior. However, the differences in abundance were only significant in the winter. Among the exotic species present in the assemblage, Drosophila suzukii Matsumura, 1931 was the only one able to more frequently use the interior of the forest and was also more likely to use areas of pristine vegetation than the other exotic species (Drosophila ananassae, D. buscki, D. immigrans, D. melanogaster and D. simulans), which were restricted to the sample plots near the edge of the forest fragment. Drosophila suzukii Matsumura, 1931 is an invasive species that only recently arrived in Bra- 
zil and in recent years has considerably expanded its distribution in the American continent, establishing in habitats with different physiognomies (Hauser 2011; Cini, Loriatti, Anfora 2012; Deprá et al. 2014; Dos Santos et al. 2017).

The seasonal edge effect observed in this study may suggest two scenarios. Firstly, the vegetation of the forest fragment may be less permeable for species associated with the matrix in periods of lower temperature. The species that invade degraded, high stress environments, such as Drosophila suzukii Matsumura, 1931, D. ananassae Doleschall, 1858, D. buscki Coquillett, 1901, D. immigrans Sturtevant, 1921, D. melanogaster Meigen, 1830 and D. simulans Sturtevant, 1919 are, in their majority, exotic to the Neotropical region (Saavedra et al. 1995; Ferreira and Tidon 2005; Silva et al. 2005; Gottschalk et al. 2007). Gottschalk et al. (2007) have previously suggested this scenario based on their study of Drosophilidae along an environmental gradient associated with urbanization in the south of Brazil. These authors observed that exotic species associated with the urban environments, like $D$. simulans Sturtevant, 1919, were not collected in non-urban or less urbanized areas during the winter, even when the species were present in the highly urbanized areas. However, in the other seasons of the year, they were highly abundant in all areas.

The second possible scenario to explain the seasonal edge effect observed is that abundances of exotic species are generally lower during the cooler seasons of the year, such that probability of capture/detection is lower and the pattern encountered during warmer times cannot be detected due to lower sample size. This variation in the abundance of Drosophilidae species is well documented for the state of Rio Grande do Sul (Franck and Valente 1985; Saavedra et al. 1995; Silva et al. 2005; Poppe et al. 2013). In addition, winter is the only season wherein species abundance and richness are greater inside the forest fragment, and is the only time of the year that the assemblage is dominated by native species. Thus, vegetation fragments may be functioning as a refuge for native species at these times of the year. Moreover, the ecological niche of Drosophilidae is not stable throughout the year, and their abundance and occurrence depend on climatic variations that influence the behavior of flies and the phenology of plants which, in turn affect the availability of food resources and oviposition sites (Valente and de Araújo 1991).

In conclusion, the results of the present study show that Drosophilidae are sensitive to edge effects in the Restinga fragment studied, and that their overall abundance is significantly higher in the interior than at the edge of the fragment in the winter. In terms of species composition, we show that most of the species sampled use both environments near the edge and environments in the interior of the forest fragment, but with different intensities. Finally, we show that some species were restricted to edge or interior environments, suggesting that certain species have different habitat use strategies. Our results provide important direction for future research, and have broad implications for the conservation of Drosophilidae. Small Restinga forest fragments, such as the one studied here, can contribute to the persistence of assemblages, thus improving the habitat quality of small fragmented forests that may be important for the maintenance of biodiversity. 


\section{Acknowledgements}

We thank Dr. Cristiano Agra Iserhard, Dra. Raquel Lüdke and Dra Maria João Ramos Pereira and anonymous reviewers for their helpful comments. We are grateful to Dra. Karen Mustin and Dra. Rebeca Zanini who kindly revised the manuscript for English. We also thank the funding agency Conselho Nacional de Desenvolvimento Científico e Tecnológico (CNPq) under grants numbers 472973/2013-4, 141578/2018-1 and 314120/2018-1. The collection was authorized by the Instituto Chico Mendes de Conservação da Biodiversidade (ICMBio), under permanent license for collecting biological material n 25454-1.

\section{References}

Alvares CA, Stape JL, Sentelhas PC, de Moraes Gonçalves JL, Sparovek G (2013) Köppen's climate classification map for Brazil. Meteorologische Zeitschrift 22(6): 711-728. https://doi.org/10.1127/0941-2948/2013/0507

Araújo DSD (1984) Comunidades vegetais. In: Lacerda LD, Araújo DSS, Cerqueira R, Turcq B (Eds) Restingas: Origem, Estrutura, Processos. Centro Editorial da Universidade Federal Fluminense (EUFF), Niterói, 157-158.

Azevedo NH, Martini AMZ, Oliveira A, Scarpa DL (2014) Ecologia na Restinga: uma Sequência Didática Argumentativa. Universidade de São Paulo, São Paulo, 140 pp. https:// doi.org/10.11606/9788591694808

Bächli G (2021) TaxoDros: The Database on Taxonomy of Drosophilidae. http://www.taxodros.unizh.ch [accessed 03 January 2021]

Bierregaard RO, Lovejoy TE, Kapos V, Santos AA, Hutchings RW (1992) The biological dynamics of tropical forest fragments. A prospective comparison of fragments and continuous forest. Bioscience 42: 859-866. https://doi.org/10.2307/1312085

Cavasini R, Buschini MLT, Machado LPB, Mateus RP (2014) Comparison of Drosophilidae (Diptera) assemblages from two highland Araucaria Forest fragments, with and without environmental conservation policies. Brazilian Journal of Biological Sciences 74(4): 761-768. https://doi.org/10.1590/1519-6984.00113

Cini A, Loriatti C, Anfora G (2012) A review of the invasion of Drosophila suzukii in Europe and a draft research agenda for integrated pest management. Bulletin of Insectology 65: 149-160. https://openpub.fmach.it/handle/10449/21029

De Toni DC, Gottschalk MS, Cordeiro J, Hofmann PRP, Valente VLS (2007) Study of the Drosophilidae (Diptera) communities on Atlantic Forest islands of Santa Catarina State, Brazil. Neotropical Entomology 36(3): 356-375. https://doi.org/10.1590/S1519-566X2007000300004

Deprá M, Poppe JL, Schimtz HJ, De Toni DC, Valente VLS (2014) The first records of the invasive pest Drosophila suzukii in South American Continent. Journal of Pest Science 87(3): 379-383. https://doi.org/10.1007/s10340-014-0591-5

Döge JS, Valente VLS, Hofmann PRP (2008) Drosophilids (Diptera) from an Atlantic Forest Area in Santa Catarina, Southern Brazil. Revista Brasileira de Entomologia 52(4): 615-624. https://doi.org/10.1590/S0085-56262008000400013 
Dos Santos LA, Mendes MF, Krüger AP, Blauth ML, Gottschalk MS, Garcia FRM (2017) Global potential distribution of Drosophila suzukii (Diptera: Drosophilidae). PLoS One 12(3): e0174318. https://doi.org/10.1371/journal.pone.0174318

Dray S, Dufour AB (2007) The ade4 package: Implementing the duality diagram for ecologists. Journal of Statistical Software 22(4): 1-20. https://doi.org/10.18637/jss.v022.i04

Ecological Data Analysis (2002) Exploratory and Euclidean methods in Environmental sciences. http://pbil.univ-lyon1.fr/ade4/home.php?lang=eng

Estação Agroclimatológica de Pelotas (Capão do Leão) (1988) http://agromet.cpact.embrapa.br/estacao/index.html [accessed 13 February 2015]

Ewers RM, Didham RK (2007) The effect of fragment shape and species sensitivity to habitat edges on animal population size. Conservation Biology 21(4): 926-936. https://doi. org/10.1111/j.1523-1739.2007.00720.x

Fahring L (2003) Effects of habitat fragmentation on biodiversity. Annual Review of Ecology Evolution and Systematics 34(1): 487-515. https://doi.org/10.1146/annurev.ecolsys.34.011802.132419

Ferreira LB, Tidon R (2005) Colonizing potential of Drosophilidae (Insecta, Diptera) in environments with different grades of urbanization. Biological Conservation 14: 1809-1821. https://doi.org/10.1007/s10531-004-0701-4

Franck G, Valente VLS (1985) Study on the fluctuation in Drosophila populations of Bento Gonçalves, RS, Brazil. Revista Brasileira de Biologia 45: 133-141.

Freire-Maia N, Pavan C (1949) Introdução ao estudo d Drosophila. Cultus 1: 1-71.

Furtado IS, Martins MB (2018) The impacts of land use intensification on the assembly of drosophilidae (Diptera). Global Ecology and Conservation 16: e00432. https://doi. org/10.1016/j.gecco.2018.e00432

Gadelha BQ, Ferraz ACP, Coelho VMA (2009) A importância dos Mesembrinelíneos (Diptera: Calliphoridae) e seu potencial como indicadores de preservação ambiental. Oecologia Brasiliensis 13: 661-665.

Google Earth and Geographic Information Science (2001) Google Earth and Geographic Information Science. http://www.google.com.br/earth/ [accessed 19 February 2013]

Gottschalk MS, De Toni DC, Valente VLS, Hofmann PRP (2007) Changes in Brazilian Drosophilidae (Diptera) assemblages across an urbanisation gradient. Neotropical Entomology 36(6): 848-862. https://doi.org/10.1590/S1519-566X2007000600005

Grimaldi DA (1987) Phylogenetics and taxonomy of Zygothrica (Diptera, Drosophilidae. Bulletin of the American Museum of Natural History 186: 103-268.

Guerra E, Streher NS, Ludtke R (2015) Plantas trepadeiras do Horto Botânico Irmão Teodoro Luís, sul do Rio Grande do Sul, Brasil. Revista Brasileira de Biociências 13: 201209. http://www.ufrgs.br/seerbio/ojs/index.php/rbb/article/view/3181

Hammer O, Harper DAT, Ryan PD (2001) PAST: Paleontological Statistics Software Package for Education and Data Analysis. Palaeontol. Electronica. http://palaeo-electronica. org/2001_1/past/issue1_01.htm

Haridas CV, Meinke LJ, Hibbard BE, Siegfried BD, Tenhumberg B (2016) Effects of temporal variation in temperature and density dependence on insect population dynamics. Ecosphere 7(5): 1-12. https://doi.org/10.1002/ecs2.1287 
Hauser M (2011) A historic account of the invasion of Drosophila suzukii (Matsumura) (Diptera: Drosophilidae) in the continental United States, with remarks on their identification. Pest Management Science 67(11): 1352-1357. https://doi.org/10.1002/ps.2265

Heimonen K, Lwanga JS, Mutanen M, Nyman T, Roininen H (2013) Spatial and temporal variation in community composition of herbivorous insects on Neoboutonia macrocalyx in a primary tropical rain forest. Journal of Tropical Ecology 29(3): 229-241. https://doi. org/10.1017/S0266467413000151

IBGE (Instituto Brasileiro de Geografia e Estatística) (1997) Unidades Climáticas. http:// www.ibge.gov.br [accessed 03 September 2014]

Jaccard P (1900) Contribution au proble'me de l'immigration post-glaciare de la flore alpine. Bulletin de la Société vaudoise des sciences naturalles 36: 87-130.

Kaneshiro KY (1969) A study of the relationships of Hawaiian Drosophila species based on the external male genitalia. Austin: University of Texas Publication 6918: 55-70. http:// www.drosophila.jp/jdd/class/030708/03070899

Kapos V (1989) Effect isolation on the water status of forest patches in the Brazilian. Journal of Tropical Ecology 5(2): 173-185. https://doi.org/10.1017/S0266467400003448

Krebs CJ (1999) Ecological Methodology. Addison Wesley Longman, Menlo Park, 620 pp.

Laurance WF, Nascimento HEM, Laurance SG, Andrade A, Ewers RM, Harms KE, Luizão RCC, Ribeiro JE (2007) Habitat fragmentation, variable edge effects, and the landscape-divergence hypothesis. PLoS ONE 2(10): e1017. https://doi.org/10.1371/journal. pone. 0001017

Laurence WF (2000) Do edge effects occur over large spatial scales? Trends in Ecology \& Evolution 15(4): 134-135. https://doi.org/10.1016/S0169-5347(00)01838-3

Lennon JJ, Turner JRG, Connell D (1997) A metapopulation model of species boundaries. Oikos 78(3): 486-502. https://doi.org/10.2307/3545610

Mantel NA (1967) The detection of disease clustering and a generalized regression approach. Cancer Research 27: 209-220.

Martins MB (1989) Invasão de fragmentos florestais por espécies oportunistas de Drosophila (Diptera, Drosophilidae). Acta Amazonica 19(0): 265-271. https://doi. org/10.1590/1809-43921989191271

Mata RA, McGeoch MA, Tidon R (2008) Drosophilid assemblages as a bioindicador system of human disturbance in the Brazilian Savanna. Biodiversity and Conservation 17(12): 2899-2916. https://doi.org/10.1007/s10531-008-9403-7

Mata RA, McGeoch MA, Tidon R (2010) Drosophilids (Insecta, Diptera) as Tools for Conservation Biology. Natureza \& Conservação 8(01): 60-65. https://doi.org/10.4322/natcon.00801009

Mateus RP, Machado LPB, Simão-Silva DP (2018) Drosophila (Diptera: Drosophilidae) survey in an 'island' of xerophytic vegetation within the Atlantic Forest biome, with emphasis on the repleta species group. Studies on Neotropical Fauna and Environment 53(2): 1-10. https://doi.org/10.1080/01650521.2018.1438082

Mendes MF, Valer FB, Vieira JGA, Blauth ML, Gottschalk MS (2017) Diversity of Drosophilidae (Insecta, Diptera) in the Restinga forest of Southern Brazil. Revista Brasileira de Entomologia 61(3): 248-256. https://doi.org/10.1016/j.rbe.2017.05.002 
Moran PAP (1950) Notes on continuous stochastic phenomena. Biometrika 37(1-2): 17-23. https://doi.org/10.1093/biomet/37.1-2.17

Murcia C (1995) Edge effects in fragmented forests: Implications for conservation. Trends in Ecology \& Evolution 10(2): 58-62. https://doi.org/10.1016/S0169-5347(00)88977-6

Neto SS, Monteiro RC, Zucchi RA, Moraes RCB (1995) Uso da análise faunística de insetos na avaliação do impacto ambiental. Scientia Agrícola 52(1): 9-15. https://doi. org/10.1590/S0103-90161995000100003

New TR (1997) Are Lepidoptera an effective "umbrela group" for biodiversity conservation? Journal of Insect Conservation 1(1): 5-12.

New TR, Pyle RM, Thomas JA, Hammond PC (1995) Butterfly Conservation Management. Annual Review of Entomology 40(1): 57-83. https://doi.org/10.1146/annurev. en.40.010195.000421

Oksanen J, Kindt R, Legendre P, O’Hara R, Simpson GL, Stevens MHH (2008) Vegan: community ecology package. $\mathrm{R}$ package version 1.13-0.

Oliveira MA, Gomes CFF, Pires EM, Marinho CGS, Della Lucia TMC Oliveira MAde (2014) Bioindicadores ambientais: Insetos como um instrumento desta avaliação. Revista Ceres 61(suppl): 800-807. https://doi.org/10.1590/0034-737x201461000005

Penariol LV, Madi-Ravazzi L (2013) Edge-interior differences in the species richness and abundance of drosophilids in a semideciduous forest fragment. SpringerPlus 2(1): 1-7. https://doi.org/10.1186/2193-1801-2-114

Poppe JL, Valente VLS, Schmitz HJ (2013) Population dynamics of Drosophilids in the Pampa Biome in response to temperature. Neotropical Entomology 42(3): 269-277. https:// doi.org/10.1007/s13744-013-0125-5

Powell JR (1997) Progress and Prospects in Evolutionary Biology. The Drosophila Model. Oxford University Press, Oxford, 562 pp.

R Core Team (2013) R: A language and environment for statistical computing. R Foundation for Statistical Computing, Viena. http://www.r-project.rg/

Ricklefs RE (2003) A Economia da Natureza. Guanabara Koogan Editora, Rio de Janeiro.

Ries L, Debinski DM (2001) Butterfly responses to habitat edges in the highly fragmented prairies of Central Iowa. Journal of Animal Ecology 70(5): 840-852. https://doi. org/10.1046/j.0021-8790.2001.00546.x

Rodrigues ENL (2005) Araneofauna de serapilheira de duas áreas de uma mata de Restinga no município de Capão do Leão, Rio Grande do Sul. Biotemas 18: 73-92.

Saavedra CCR, Callegari-Jacques SM, Napp M, Valente VLS (1995) A descriptive and analytical study of four Neotropical drosophilid communities. Journal of Zoological Systematics and Evolutionary Research 33(3-4): 62-74. https://doi.org/10.1111/j.1439-0469.1995. tb00957.x

Saito T, Toriwaki JI (1994) New algorithms for Euclidean distance transformation of an n-dimensional digitized picture with applications. Pattern Recognition 27(11): 1551-1565. https://doi.org/10.1016/0031-3203(94)90133-3

Scarano FR (2009) Plant communities at the periphery of the Atlantic rain forest: Rarespecies bias and its risks for conservation. Biological Conservation 142(6): 1201-1208. https://doi.org/10.1016/j.biocon.2009.02.027 
Schmitz HJ, Valente VLS (2019) The flower flies and the unknown diversity of Drosophilidae (Diptera): A biodiversity inventory in the Brazilian fauna. Papéis Avulsos de Zoologia 59: e20195945. https://doi.org/10.11606/1807-0205/2019.59.45

Silva NM, Fantinel Cda C, Valente VLS, Valiati VH (2005) Ecology and populations dynamics of the invasive species Zaprionus indianus (Gupta) (Diptera: Drosophilidae) on the composition of the Drosophilid communities in Porto Alegre city, Southern of Brazil. Neotropical Entomology 34: 363-374. https://doi.org/10.1590/S1519566X2005000300002

Souza C, Suguio K, Santos A, Oliveira P (2005) Quaternário do Brasil [Geologia e Geomorfologia de Regiões Costeiras]. Holos Editora, Ribeirão Preto.

Sturtevant AH (1921) The North American species of Drosophila. Carnegie Institute of Washington Publication 301: 1-150. https://doi.org/10.5962/bhl.title.33564

Tidon R, Sene FM (1988) A trap that retains and keeps Drosophila alive. Drosophila Information Service 67: e89.

Torres FR, Madi-Ravazzi L (2006) Seasonal variation in natural populations of Drosophila spp. (Diptera) in two woodlands in the State of São Paulo, Brazil. Iheringia. Série Zoologia 96(4): 437-444. https://doi.org/10.1590/S0073-47212006000400008

Valente VL, de Araújo AM (1991) Ecological aspects of Drosophila species in two contrasting environments in southern Brazil (Diptera, Drosophilidae). Revista Brasileira de Entomologia 35: 237-253.

Vickery PD (2002) Effects of the Size of Prescribed Fire on Insect Predation of Northern Blazing Star, a Rare Grassland Perennial. Conservation Biology 16(2): 413-421. https:// doi.org/10.1046/j.1523-1739.2002.00494.x

Wheeler MR, Kambysellis MP (1966) Notes on the Drosophilidae (Diptera) of Samoa. The University of Texas Publication 6615: 533-565.

Wink C, Guedes JVC, Fagundes CK, Rovedder AP (2005) Insetos edáficos como indicadores da qualidade ambiental. Revista de Ciências Agroveterinárias 4: 60-71. 


\section{Supplementary material 1}

\section{Tables S1-S7}

Authors: Mayara Ferreira Mendes, Monica Laner Blauth, Luana Amaral Dos Santos, Vera Lúcia da Silva Valente Gaiesky, Marco Silva Gottschalk

Data type: statistical data

Explanation note: Table S1. Mantel and Moran's I tests. Table S3. Spearman's correlation index (Rs) values and significance (p) of the correlations between species richness and absolute Drosophilidae abundance and distance for the edge of the analyzed vegetation fragment, for the four seasons of the studied year. Table S4. Results of the SIMPER analysis comparing the Drosophilidae assemblages from the interior and edge of a fragment of Restinga in southern Brazil, during Winter. Table S5. Results of the SIMPER analysis comparing the Drosophilidae assemblages from the interior and edge of a fragment of Restinga in southern Brazil, in the Spring season. Table S6. Results of the SIMPER analysis comparing the Drosophilidae assemblages from the interior and edge of a Restinga fragment in the South of Brazil, during Summer. Table S7. Results of the SIMPER analysis comparing the Drosophilidae assemblages from the interior and edge of a Restinga fragment in southern Brazil, during Autumn.

Copyright notice: This dataset is made available under the Open Database License (http://opendatacommons.org/licenses/odbl/1.0/). The Open Database License $(\mathrm{ODbL})$ is a license agreement intended to allow users to freely share, modify, and use this Dataset while maintaining this same freedom for others, provided that the original source and author(s) are credited.

Link: https://doi.org/10.3897/neotropical.16.e61481.suppl1 